
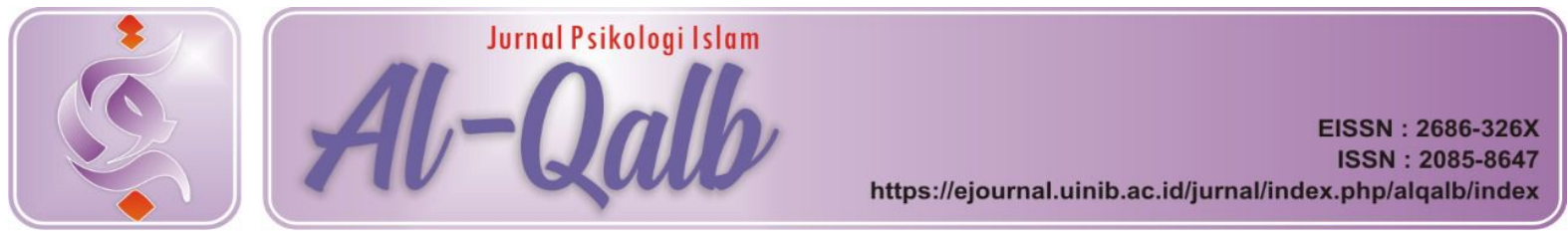

\title{
PENYESUAIAN DIRI HOMOSEKSUAL
}

Received: $26^{\text {th }}$ December 2014; Revised: 07 ${ }^{\text {th }}$ January 2015; Accepted: $18^{\text {th }}$ February 2015

Subhan Ajrin Sudirman

IAIN Imam Bonjol Padang

Email: subhanajrin@gmail.com

\begin{abstract}
Abstrak. Keberadaan homoseks merupakan fenomena sosial yang saat ini ada di sekitar masyarakat Indonesia pada umumnya. Homoseksual adalah seseorang yang memilih relasi seks pada jenis kelamin yang sama, seorang laki-laki akan memilih laki-laki sebagai pasangan dalam relasi seksualnya, begitupula dengan perempuan memilih perempuan sebagai relasi seksnya. Keberadaan mereka tidak dapat dipungkiri dan menjadi semakin tajam karena ada keterbukaan dalam mengungkap jati diri mengenai siapa mereka sebenarnya. Hubungan yang terjadi pada homoseksual adalah sebuah hubungan yang bersifat erotis dan mengacu pada perilaku seksual. Orang akan menilai wajar apabila melihat dua orang wanita yang saling bergandengan mesrabahkan bila melihat sepasang wanita salin berciuman pipi di tempat umum. Perilaku tersebut akan dinilai lain apabila dilakukan oleh sepasang lakilaki, orang awam akan merasa risih atau heran dengan perilaku mereka, bahkan tak jarang hal ini akan mejadi buah bibir dan bahan cemoohan bagi masyarakat kebanyakan. Permasalahan yang tengah dihadapi oleh homoseks khususnya gay di Indonesia adalah mengenai keberadaannya yang masih terasa asing di lingkungan masyarakat umum. Kebanyakan dari masyarakat akan menganggap bahwa gay adalah suatu aib yang memalukan keluarga dan anggapan bahwa gay adalah yang menyebabkan munculnya penyakit AIDS. Namun kenyataannya, sampai saat ini gay tetap berjuang menunjukkan eksistensi dirinya serta melawan diskriminasi sosial yang terusmenerus muncul disekitarnya.
\end{abstract}

Kata kunci: Penyesuaian diri, homoseksual

$\mathrm{M}$ anusia sebagai makhluk sosial baik dalam kondisi yang normal atau mengalami kelainan dalam perkembangan jasmani maupun sosial akan selalu membutuhkan orang lain dalam hidupnya. Di samping hubungan sosial biasa, di antara wanita dan pria bisa terjadi hubungan khusus, yang sifatnya erotis, yang disebut dengan relasi seksual. Hubungan seksual yang normal mengandung pengertian bahwa hubungan tersebut tidak menimbulkan efek-efek yang merugikan, baik bagi diri sendiri maupun bagi pasangannya, serta tidak menimbulkan konflik-konflik psikis dan tidak bersifat paksaan atau perkosaan (Kartono, 1989).

Dalam pandangan budaya pada umumnya laki-laki dan wanita dewasa harus 
mampu melakukan relasi seksual yang adekuat. Dengan kata lain, wanita disebut normal dan dewasa bila dia mampu mengadakan relasi seksual dengan seorang pria dalam bentuk normal dan bertanggungjawab. Sebaliknya, seorang pria disebut normal dan bertanggungjawab dalam arti kedua belah pihak menyadari akan konsekuensinya serta berani memikul tanggungjawab terhadapnya.

Sisi lain kehidupan yang sering menjadi sorotan masyarakat luas adalah ketika seseorang memilih relasi seks pada jenis kelamin yang sama, yang disebut sebagai homoseksual (Kartono, 1989). Homoseksual terdapat dalam begitu banyak masyarakat di dunia yang senantiasa memikat untuk dipahami. Pada awalnya siapapun tentu saja tidak ingin jadi homoseks, tetapi kalau akhirnya terlahir menjadi homoseks siapapun sulit menolaknya. Karena seperti sifat dasar lainnya, kecendrungan perilaku homoseksual tersebut tidak bisa diubah. Pada dasarnya perilaku tersebut merupakan sifat bawaan yang terus melekat selama hidupnya (Tatung, 1998).

Pria homoseks dikenal dengan sebutan "gay" dan wanita homoseks dikenal dengan sebutan "lesbian". Untuk saat ini gay lah yang paling banyak disoroti masyarakat karena lesbian lebih banyak tertutup dan tidak kentara. Masyarakat cenderung masih menganggap wajar bila ada dua wanita yang bergandengan tangan atau berciuman pipi di tempat umum, tetapi akan lain kesannya jika yang melakukan hal itu sepasang pria.

Permasalahan yang dihadapi homoseks di Indonesia adalah mengenai keberadaan mereka yang masih terasa asing untuk bisa diterima di lingkungan masyarakat. Hal ini dapat dilihat dari kenyataan bahwa sebagian masyarakat memandang homoseksualitas adalah simbol kekejian, suatu aib yang memalukan keluarga. Terlebih sejak ditemukannya penyakit AIDS yang mengerikan, homoseks semakin lebih banyak dipersalahkan. Pada sisi lain, homoseks tetap berjuang menunjukkan eksistensi diri serta melawan diskriminasi sosial yang ada.

\section{PEMBAHASAN}

\section{Deskripsi Gejala}

Permasalahan mengenai adanya gangguan penyesuaian diri minoritas ini ditunjukkan dengan adanya JLGI (Jaringan Lesbian dan Gay Indonesia) sebagai organisasi bagi orang-orang homoseks. Salah satu organisasi yang bernaung didalamnya adalah GAYa NUSANTARA untuk kota Surabaya. Kelompok ini juga menerbitkan sebuah bulletin dengan nama yang sama atau sering disingkat dengan nama GN. Gaya merupakan pelesetan dari kata "gay" sedang "nusantara" menggambarkan bahwa kelompok ini berskala nasional maksudnya untuk seluruh gay Indonesia. Organisasi ini didirikan oleh Dede Oetomo beserta pasangannya Rudy Mustapha pada tanggal 1 Agustus 1987 KKLGN (Kelompok Kerja Lesbian dan Gay Nusantara) resmi berdiri dengan tujuan utama adalah agar gay, lesbian serta waria diterima sebagai kelompok yang hak dan kewajibannya sama dengan heteroseksual di masyarakat Indonesia.

Namun, jika berbicara tentang masalah homoseksualitas sulit untuk tidak melihat adanya sanksi sosial masyarakat seperti yang diungkapkan oleh ketua BAGASY (Batam Gay Society) dalam pernyataannya (Buletin GAYa Nusantara, 1998). Adanya penolakan dari masyarakat tersebut yang mendorong homoseks cenderung menjadi tertutup. Ratarata homoseks di Indonesia masih diliputi rasa ketakutan bila masyarakat mengetahui jati dirinya sebagai seorang homoseks. Konsep ketimuran pada budaya Indonesia dan kehidupan agamis yang kental sering menjadi halangan bagi gay untuk 
14 Jurnal Al-Qalb, Jilid 7, Nomor 1, Maret 2015, hlm. 12-17

bersosialisasi dan bergaul dengan masyarakat. Gay sudah begitu identik dengan dosa besar, penyakit, kelainan jiwa, psikopat dan lain sebagainya yang dipicu juga oleh perlakuan media massa yang terkadang bersikap diskriminatif dengan menggulirkan informasi-informasi yang justru mempertegas nilai negatif gay sehingga gay semakin menutup diri. (Buletin GAYa Nusantara, 1998). Berkaitan dengan hal diatas maka penulis mempunyai dugaan bahwa individu yang mempunyai relasi seks sejenis tersebut sebenarnya mempunyai problem dalam dirinya dan dalam menyesuaikan diri dengan lingkungannya. Disini juga penulis ingin mengetahui hal-hal apa saja yang melatarbelakangi munculnya masalah penyesuaian diri tersebut.

\section{Analisis Gejala}

Seperti yang telah dipaparkan diatas bahwa homoseks tersebut mempunyai masalah dengan penyesuaian diri terhadap lingkungannya. Pada sisi lain penyesuaian diri merupakan aspek penting dalam kehidupan manusia, baik sebagai makhluk individu maupun makhluk sosial. Menurut Fahmi (1982) penyesuaian diri terdiri dari aspek pribadi yang berupa penerimaan atas diri, tidak benci pada diri sendiri, tidak merasa gelisah, beremosi stabil, tidak ada rasa bersalah dan puas atas keberadaan dirinya, serta aspek sosial berupa kemampuan individu berinteraksi dengan masyarakat. Selain itu menurut Schneiders (1964), penyesuaian diri adalah proses yang melibatkan respon mental dan tingkah laku dimana individu berusaha menanggulangi kebutuhan-kebutuhan dalam dirinya, mengatasi ketegangan, frustrasi dan konflik. Adapun tujuan proses penyesuaian diri adalah terciptanya keselarasan antara tuntutan dari dalam diri individu dengan tuntutan lingkungannya.
Manson (dalam Meichati, 1974) mengungkapkan bahwa penyesuaian diri mengandung dua macam unsur, yaitu penyesuaian di dalam diri individu sendiri yang menyangkut ada atau tidaknya kesukaran psikologik seperti kecemasan, keadaan tertekan (depresiveness) dan sensitivitas emosi serta penyesuaian sosial yang menyangkut kehidupan individu dalam hubungan sosial seperti resentfullness (perasaan benci atau dendam kepada masyarakat maupun individu lain), kegagalan sosial, perasaan terasing dan hubungan antar pribadi.

Demikian pula yang terjadi pada homoseks yang dikatakan memiliki kelainan dalam bidang orientasi seksualnya tetap memiliki keinginan untuk diterima dalam keluarga dan lingkungannya seperti manusia normal lainnya. Namun dalam kenyataannya masyarakat belum bisa menerimanya, sebagaimana ungkapan "gay" yang menyatakan bahwa "kami adalah yang tersisih" yang mengandung pengertian bahwa "gay" pada akhirnya tetap dilecehkan dan menjadi warga yang marginal dan introvert. Hal ini berakibat pada tidak terpenuhinya kebutuhan psikologis sosial mereka dan membuat mereka mengalami kesulitan dalam bersosialisasi dengan masyarakat karena adanya ketidaksesuaian antara tingkah laku dengan norma masyarakat.

Kegiatan seksual yang tidak dalam kerangka sosial yang lazim akan diancam rasa bersalah bagi pelakunya, malah oleh agama dikecam sebagai dosa. Heteroseks dihujat jika melakukan hubungan seks diluar perkawinan, sementara homoseks seolaholah tidak mempunyai hak seksual karena otomatis kegiatan seksual bagi mereka ada diluar perkawinan dan pasti menyimpang. Diskriminasi dan rasa bersalah yang ditanamkan pada diri homoseksual mengakibatkan mereka menutupi orientasi 
seksualnya, dengan akibat lanjut penekanan jiwa yang sering parah. Setiap kali dorongan seksualnya muncul menyusuplah konflik antara ingin seks dan dosa serta takut diketahui oleh orang lain. Bila konflik dan rasa bersalah ini tidak teratasi maka akan dapat berlanjut pada terjadinya kecemasan yang berlebihan dan kondisi depresi. Baik kecemasan maupun depresi menurut Manson (dalam Meichati, 1974) merupakan indikator terjadinya gangguan penyesuaian diri.

Keadaan demikian dapat mengganggu perkembangan jiwa dan dapat mempengaruhi perkembangan karir sehingga keadaan jiwa yg terganggu itu membuat gay tidak dapat bergaul sebagaimana mestinya. Dan kalaupun mereka memaksakan diri untuk dapat bergaul di masyarakat mereka harus memainkan peran seakan-akan atau seolah-olah bukan seorang homoseksual tetapi heteroseksual. Ini adalah sebuah cara untuk berpretensi, membuat kamuflase, menampilkan fatamorgana, yaitu tindakan berpretensi seakan-akan sesuatu itu nyata padahal tidak.

Berdasarkan uraian di atas tampak bahwa homoseks mengalami masalah dengan hal penyesuaian dirinya, baik hubungan dengan dirinya sendiri maupun kehidupan sosialnya. Hasil analisis diatas menunjukkan bahwa pada umumnya homoseks mengalami gangguan pada semua aspek penyesuaian diri tetapi yang paling menonjol ialah hambatan pada aspek kecemasan dan kegagalan sosial.

Dari beberapa sumber dapat diperoleh beberapa informasi, yang pertama adalah bahwa subjek memandang hidupnya dengan wajar dan optimis walaupun didalamnya masih tersimpan konflik mengenai keadaan dirinya yang berbeda dengan orang lain pada umumnya. Perasaan kacau , kalut dan bingung serta tidak habis mengerti tentang apa yang terjadi pada dirinya. Untuk mengatasi konfliknya biasanya individu melakukan perilaku koping dengan berserah diri pada Tuhan dengan menerima diri apa adanya. Perilaku yang dilakukan individu tersebut menerima kompensasi hubungan subjek dengan keluarga terjalin rasa saling menghargai dan mau mengerti keadaan individu tersebut. Hal ini menambah optimis individu untuk menjalani kehidupan ini dengan positif, wajar, optimis dan menyadari bahwa perbedaan dalam dirinya merupakan suatu hal yang tidak mudah diterima masyarakat. Oleh karena itu subjek menghargai kehidupan pribadi setiap orang yang tentunya berbeda.

Lain halnya dengan subjek yang berikutnya, yang menerima konsekuensi bahwa dirinya memang terlahir sebagi seorang gay karena dirinya yakin bahwa Tuhan memberinya keadaan ini pasti ada sesuatu yang besar dibalik semua ini. Penerimaan diri yang utuh dan pemikiran positif subjek bermanfaat untuk mencegah timbulnya gangguan penyesuaian diri. Semua itu ia dapatkan melalui proses setelah sebelumnya melakukan proyeksi (dengan menyalahkan Tuhan) yang dirasakannnya kurang bijaksana. Hal tersebut membantu subjek dalam proses penyesuaian dirinya.

Subjek selanjutnya memperlihatkan adanya serangkaian kegagalan sosial yang ditunjukkan dengan penuturannya bahwa masa kecilnya sering menjadi bahan ejekan teman-temannya karena ciri-ciri kefeminiman itu terlihat. Usahanya untuk dekat wanitapun hanya membuatnya tersiksa padahal di dalam dirinya menganganangankan pula dilahirkan sebagai seorang yang heteroseksual. Hal tersebut menandakan bahwa meskipun diri sendiri dan orang tua mampu menerima kondisinya namun pandangan masyarakat yang negatif terhadap gay merupakan hal yang mengganggu pergaulan sosialnya. Subjek ini juga menunjukkan bahwa dia memiliki masalah dengan penyesuaian dirinya, yang selalu memunculkan perang batin antar kebutuhan dasar seksnya dengan cara yang 
ia lakukan yang bertentangan dengan kata hatinya sehingga hal tersebut menimbulkan kegelisahan dan kebimbangan dalam dirinya. Di lain pihakpun ia sangat perasa sehingga ia tidak ingin mengecewakan keluarganya dengan menyembunyikan identitas ke-gayannya dan menganggap belum waktunya untuk lebih terbuka pada mereka. Kegagalan dalam hubungan keluarga dipengaruhi pula oleh masa lalunya yang merindukan kasih sayang dari ayahnya. Sebagai pertahanan diri, subjek menggunakan pendekatan emosional dengan pasrah dan berserah diri pada Tuhan.

Subjek selanjutnya memandang dirinya memiliki kelainan antara fisik dan jiwanya, yaitu kondisi fisik laki-laki tetapi tidak bisa menyukai lawan jenisnya. Hal ini menimbulkan kecemasan, kesedihan dan suasana hati susah. Subjek berusaha menerima keadaan dirinya namun terbentur oleh norma-norma di masyarakat sehingga dapat dilihat ia memiliki rasa sentimen yang kuat dan pahit pada masyarakat, dengan kata lain perasaan benci dan dendam pada masyarakat maupun individu lain sehingga ia memiliki serangkaian kegagalan sosial dan partisipasi masyarakat dan ia berusaha juga menutupi keadaan dirinya dari lingkungan sekeliling. Dia baru akan merasakan kenyamanan di sekeliling orangorang yang senasib yang dirasakannya bisa mengerti dan memahami perasaannya.

Dari paparan di atas sesuai dengan pendapat Garrinson (dalam Rihayanti, 1999) yang mengatakan bahwa setiap individu memiliki masalah yang berhubungan dengan penyesuaian diri. Ditambahkan pula oleh Schneiders (1964) yang mengemukakan bahwa faktor-faktor yang mempengaruhi penyesuaian diri salah satu diantaranya ialah kondisi fisik. Karena itu, orang-orang homoseks yang memiliki kondisi fisik yang berbeda dengan orang-orang pada umumnya membatasi ruang gerak di lingkunagnnya yang dapat berpengaruh pada proses penyesuaian diri.

Fahmi (1982) mengungkapkan banyak faktor yang mempunyai pengaruh besar dalam menciptakan penyesuaian diri pada individu, di antaranya yang terpenting adalah adanya penerimaan terhadap dirinya sendiri. Hal tersebut akan mempengaruhi kelakuannya. Pada subjek yang memiliki penyesuaian diri yang baik dapat dilihat memiliki pandangan yang positif mengenai diri dan kehidupannya serta mampu menerima diri secara utuh.

\section{SIMPULAN}

Dari pemaparan di atas dapat ditarik simpulan bahwa masalah penyesuaian diri pada homoseksual paling menonjol adalah gangguan kecemasan dan kegagalan sosial, termasuk didalamnya bahwa sebagian besar homoseksual mengalami permasalahan yang berat, sedang dan ringan dalam hal penyesuan diri.

Ketika dihadapkan kenyataan bahwa dirinya seorang homoseks, ada dua reaksi yang muncul, yaitu menerima dan menolak. Individu yang dapat menerima dirinya dapat meminimalkan masalah gangguan tersebut dan sebaliknya individu yang tidak bisa menerima diri dapat menambah berat permasalahan penyesuaian diri. Kualitas hubungan keluarga yang baik dapat memberikan peluang untuk mendapatkan penerimaan keluarga sehingga dapat membantu individu dalam penyesuaian dirinya. Dalam mengatasi masalahnya homoseksual ini melakukan self-defence mechanism perlu berhati-hati dan memperbaiki cara penyesuaian diri dengan mengurangi mekanisme pertahanan diri. Pada dasarnya semua homoseks ini menyadari adanya penolakan dari masyarakat mengenai kondisinya sehingga mereka memilih untuk menutupi keadaannya, tetapi ada pila yang cenderung berhati-hati 
dalam bersikap di masyarakat, kadang sikap masa bodoh dilakukannya untuk menghindari konflik. Selanjutnya, dalam masyarakat luas individu homoseks menyadari kondisinya sehingga mereka cenderung berhati-hati dalam berperilaku sehingga dapat menghambat penyesuaian sosialnya. Namun individu yang optimis dan menjalani kehidupannya dengan positif dapat mengurangi hambatan penyesuaian dirinya dan melalui interaksi dengan kelompoknya perasaan cemas yang dirasakan oleh seorang homoseks dapat berkurang.

Mungkin ke depan nanti bisa dilakukan penelitian yang lebih mendalam

\section{DAFTAR RUJUKAN}

Ahmad, (1998, November), "Gay dan Media Massa". Buletin GAYa Nusantara. No. 58.

Buletin GAYa Nusantara, (1998, November), Menengok Kehidupan Gay Batam.

Chaplin, J.P. 1972, Dictionary of Psychology, Dell Publishing Co. Inc., New York.

Fahmi, M. (1982), Penyesuaian Diri, Pengertian dan Peranannya dalam Kesehatan Mental. (terjemahan Zakiyah Daradjat). Jakarta: Bulan Bintang.

Kartono, K. (1989). Abnormalitas Seksual, Bandung: C.V. Mandar Maju. dan menyeluruh terhadap fenomena minoritas ini, karena ini sangat menarik untuk dikaji lebih jauh. Termasuk aspek lingkungan yang membentuk seseorang menjadi homoseksual atau juga aspek biologis dari seorang individu yang mungkin menjadi pemicu terhadap terbentuknya orientasi seksual seseorang yag kemudian dihadapkan dengan kondisi masyarakat umumnya, dan khususnya negara Indonesia sebagai negara yang berkembang dan masih menjunjung tinggi nilai-nilai dan adat istiadat ketimuran.
Lindzey, G and Aronson, E (Eds.), 1975. Handbook of Social Psychology. Vol. 1. Amerind, Publishing Co., Ltd., New Delhi.

Meichati, S., Swadirman, Nuryoto, S. \& Prawitasari, J.E (1974). Penyelidikan Tentang Tanggapan Remaja Mengenai Diri dan Kehidupannya. Yogyakarta: Fakultas Psikologi UGM.

Schneiders, A.A. (1964). Personal Adjusment and Mental Health. New York: Holt, Rinehart and Winston.

Tatung, P. (1998, Agustus). "Gay Bukan Kelompok Aneh". Dalam Tabloid MINGGU INI. Edisi 21/IX/20. 